\title{
Applying Stochastic Frontier Analysis to Measure the Operating Efficiency of Solar Energy Companies in China and Taiwan
}

\author{
Jih-Shong Wu* \\ Center for General Education, Chihlee University of Technology, New Taipei City, Taiwan
}

Received: 30 September 2019

Accepted: 10 December 2019

\begin{abstract}
Climate change and the depletion of fossil fuels are the biggest challenges that humanity faces today. Solar energy can be used to mitigate climate change and reduce the demand for fossil fuels. Therefore, governments in different countries have actively developed the solar energy industry as a renewable energy industry. Although China and Taiwan respectively occupy first and second place in the current global output of solar energy products, they face serious pressure in the international market. To measure the operating efficiency of solar energy companies in China and Taiwan, this study combines the Shephard distance function and stochastic frontier analysis incorporating environmental variables. The empirical results show that: (1) China has better labour efficiency, (2) Taiwan has better operating cost efficiency, (3) both regions have extremely poor expenditure efficiency on R\&D and the $R \& D$ expenditure rate is low, (4) the larger a company's size, the higher the labour efficiency and cost efficiency, and (5) the prices of raw materials have a direct impact on operating costs. It is hoped that the results of this research can provide recommendations for and promote changes in the operating and management strategies of the solar energy industry, improving its operating efficiency.
\end{abstract}

Keywords: solar energy industry, efficiency measure, stochastic frontier analysis, climate change

\section{Introduction}

Since the industrial revolution of the $1750 \mathrm{~s}$, human economic activities have developed rapidly. The extensive burning of fossil fuels (such as raw coal, crude oil, and natural gas) has led to continued increases in the concentrations of greenhouse gases in the atmosphere - such as water vapor $\left(\mathrm{H}_{2} \mathrm{O}\right)$, carbon dioxide $\left(\mathrm{CO}_{2}\right)$, methane $\left(\mathrm{CH}_{4}\right)$, nitrous oxide $\left(\mathrm{N}_{2} \mathrm{O}\right)$,

*e-mail: jishong@mail.chihlee.edu.tw ozone $\left(\mathrm{O}_{3}\right)$, chlorofluorocarbons (CFCs) and Hydro fluorocarbons (incl. HCFCs and HFCs), which all lead to climate change. Since the beginning of the industrial revolution we have produced a $40 \%$ increase in the atmospheric concentration of carbon dioxide $\left(\mathrm{CO}_{2}\right)$, the full record being from $340 \mathrm{ppm}$ in 1980 to $409 \mathrm{ppm}$ in early 2018 [1].

Fossil energy resources such as coal, oil and natural gas account for the largest proportion of energy worldwide, they also produce more environmental pollution than renewable energy [2]. The data of fossil fuel show that coal, oil and natural gas account for $85.9 \%$ of primary energy consumption. The 
International Energy Agency has predicted that global oil can be extracted for around 45 years, and coal can be extracted for round 230 years $[3,4]$. Nuclear power used nuclear reactions to release nuclear energy. The issue of nuclear power plant disasters has been the topic of social debate since the first nuclear reactor was constructed in 1954 [5]. Nuclear power plant disasters may involve significant casualties and losses of life and property. Serious nuclear power plant disasters include Three Mile Island (1979), Chernobyl (1986), and Fukushima Daiichi (2011). Since Fukushima, people have doubted the safety of nuclear power plants, and many countries have closed or are planning to close their nuclear power plants. The safety of an energy source is another big concern for selecting an alternative. Therefore, many countries have recognized that the development of safe renewable energy sources is necessary for the environment as well as the economy [6].

As environmental awareness and the need to reduce air pollution have increased, renewable energy has become an important energy source in industrialized countries [2]. The mitigations of climate change, energy demands and energy related to global warming effects are the most important factors today. However, renewable energy is one of the alternative sources that have the capacity to reduce climate change and mitigate greenhouse gas emissions [7, 8]. Natural energy sources include sunlight, wind, rain, tides, waves, and geothermal heat. Renewable energy sources include solar energy, wind energy, hydroelectric power, geothermal energy, tidal energy, and wave energy [9]. Energy researchers and policy decision makers around the world are now utilizing renewable energy as a solution to this crisis, with a special focus on solar energy, as it is one of the most non-polluting, inexhaustible and the cleanest renewable energy source $[7,8,10]$.

Renewable energy (excluding hydroelectric power) grew by $14.1 \%$ in 2016 - below the 10 -year average, but the largest increment on record (53 mtoe). Wind energy provided more than half of renewable growth, while solar energy contributed almost a third despite accounting for only $18 \%$ of the total. Asia Pacific overtook Europe and Eurasia as the largest producing region of renewable energy. China overtook the US to be the largest single renewable energy producer [3]. Recently, the tremendous growth in the world solar industry is helping to pave the way to a cleaner, more renewable energy future. Over the past few years, the cost of a solar energy system has dropped significantly and has helped to give more families and business access to affordable clean energy [11].

Solar power is the conversion of energy from sunlight into electricity. Photovoltaic cells convert light into an electric current using the photovoltaic effect. Through a portfolio of research and development (R\&D) efforts, the solar industry remains committed to leveraging a nation's abundant solar energy resources to drive research, manufacturing and market solutions to support widespread expansion of the solar market [11].

The International Energy Agency has projected that the solar photovoltaic and concentrated solar power would contribute about 16 and 11 percent, respectively, of worldwide electricity consumption, and solar power would be the world's largest source of electricity in 2050. Most solar system installations would be in China and India. As of 2016, the solar energy provided just 1\% of total worldwide electricity production but was growing at $33 \%$ per annum. China is expected to overtake Europe as the largest producer of PV electricity soon after 2020, with its share regularly increasing from $18 \%$ of global generation by 2015 to $40 \%$ by 2030 , and then slowly declining to $35 \%$ by 2050 . From 2030 to 2050 , the share of India and other Asian countries is expected to rise from $13 \%$ to $25 \%$. By contrast, the United States' share is expected to remain at about $15 \%$ from 2020 on, and Europe's share to decrease constantly from $44 \%$ in 2015 to $4 \%$ in $2045[12,13]$.

The development of the solar energy industry in China and Taiwan began later than in the West, but has now surpassed it. At present, China and Taiwan enjoy first and second places respectively in the global output value of solar energy products, with China accounting for around $70 \%$, Taiwan accounting for around $10 \%$, and Japan, South Korea, and Germany making up the rest [14]. However, the West still holds many of the major patented technologies for solar energy. In contrast, China and Taiwan lack many core technologies, which is not conducive to price competition in the international market. Moreover, in recent years Western countries have imposed import tariffs on China and Taiwan, creating a crisis in solar energy industry chains.

Although China and Taiwan are two separate economies, in terms of technological development industries such as semiconductors, they are reliant on both each other and competitors. In the solar energy industry, both China and Taiwan face the problem of ownership of proprietary technologies by the West and the blocking of these technologies. In addition, the technology gap has led to increased costs. Both China and Taiwan are also facing internal and external risks in the international market, such as price competition, raw material costs, technological research and development (R\&D), and company operating performance.

In summary, the solar energy industry in China and Taiwan is facing exposure to harsh internal and external environmental factors and risks. This study examines how to improve the operational effectiveness of the solar industry, exploring whether there are influencing factors that can be improved in the face of the impact of price competition and cost reduction in the market.

Recently, the topic of how to measure efficiency has drawn quite a bit of attention from researchers [15]. The concept of efficiency can be traced back to Farrell [16], who developed many ideas underlying data envelopment analysis (DEA) and stochastic frontier analysis (SFA) [17]. At present, the new energy industry and the solar 
photovoltaic industry used data envelopment analysis and stochastic frontier analysis to measure energy use efficiency. Wu et al. [18] applied DEA and Malmquist indices to examine the efficiency of energy utilization in thirty provinces in China. The results showed that the average efficiency of energy utilization of enterprises in the Eastern region during the period from 2006 to 2009 was better than that in the Central region. Chen and Shihong [19] applied DEA to explore the efficiency and benefits of China's solar energy industry. The results showed that the overall financing efficiency and technical efficiency are the best in the Eastern region. In addition, the Western region has the best installations of solar energy plants but also the lowest installation rates.

Tu et al. [20] used DEA to create a weight-restricted dynamic energy efficiency indicator, and discusses issues concerning the energy decoupling rate and decarbonization. This study utilized members in the Group of Seven (G7, include Canada, France, Germany, Italy, Japan, the United Kingdom, and the United States) and BRICS (Brazil, China, India, Russia, and South Africa) for the experimental observations. The findings are: (1) BRICS has more room for improvement to achieve the standard ratio of the energy decoupling rate than the G7; (2) the G7 and BRICS do not converge to decarbonization; and (3) BRICS exhibits more rapid improvement on energy efficiency than the G7. Lee and Tong [2] accurately predicted whether transfer efficiency of a photovoltaic power generation system is high or low using a novel hybrid model that combines rough set theory, data envelopment analysis, and genetic programming. Chueh and Jheng [21] used two-stage data envelopment analysis to evaluate the operating efficiency and profitability of Taiwan's listed solar cell manufacturers. This study's primary contribution is in constructing a performance evaluation model for the solar cell industry to assist relevant manufacturers in formulating operational strategies. Lee et al. [22] proposed a performance evaluation model by integrating the analytic hierarchy process and data envelopment analysis to assess the current business performance of PV companies. Stern [23] measured energy efficiency by applying SFA to 85 countries and examining the determinants of inefficiency. Herrala and Goel [24] studied global carbon dioxide (CO2) efficiency for more than 170 countries. Honma and $\mathrm{Hu}$ [25] used the SFA model to estimate the total-factor energy efficiency scores for 47 regions across Japan during the years 1996-2008. Lee et al. [26] used DEA to assess suitable locations for renewable energy plants. They used temperature and wind speed as inputs, and sunshine hours and elevation as output data to select 15 townships in Taiwan as the best places for establishing photovoltaic plants. Liu et al. [4] used DEA to construct a comprehensive evaluation model for the efficiency of photovoltaic power generation in China between 2005 and 2015, exploring the input and output efficiency of installed capacity from the perspective of resource, development, and utilization efficiencies.
In recent years, performance evaluation methods have been widely used and valued to measure the efficiency of various industries. The main reason is that decision makers in both public and private institutions want to understand whether their organization is efficiently utilizing resources. A performance assessment can serve as a reference for decision-making. In addition, indicators of efficiency of for-profit organizations are usually based on objective and quantifiable assessment methods using quantifiable financial inputs and outputs such as operating costs, incomes, and salaries. In terms of research methods for measuring efficiency, a variety of objective assessment methods have been developed, including regression analysis, multi-criteria decision analysis (MCDA), and frontier analysis. Frontier analysis often uses DEA or SFA for analysis. DEA is used by most researchers because it is simple and there is no need to construct a function. This method can be used to compare the relative efficiencies of different research subjects, but it cannot account for external environmental variables. Meanwhile, the SFA method has been widely used in many areas of performance evaluation research, but fewer studies have used this method. Nevertheless, SFA can explore the absolute efficiency and interrelationships between all of the input influencing factors and efficiencies, and can also include external environmental variables, so the effects of efficiency factors and environmental variables can be analyzed simultaneously.

This study collects publically available financial report data from listed solar energy companies in China and Taiwan. It uses the SFA method to construct an efficiency model for the solar industry in China and Taiwan in order to explore the relationships between factors affecting industry and efficiency, incorporates environmental variables to explore their impact on efficiency, and proposes future business strategies and suggestions for improvement.

\section{Material and Methods}

\section{Methodology}

To include statistical noises in efficiency analysis, Zhou et al. [27] presented a parametric frontier approach to measuring efficiency performance at an economy-wide level. The proposed approach used the Shephard distance function to define an efficiency index and applied the stochastic frontier analysis model to estimate the efficiency index. Honma and $\mathrm{Hu}$ [25] extended the cross-sectional stochastic frontier analysis proposed by Zhou et al. [27] to panel data models and add environmental variables.

This study assumes that the production function is a Cobb-Douglas function and estimates the disaggregate input efficiency for the three inputs and one output. First, the combination of input and output $\mathrm{T}$ is defined. Productivity can be described as follows [25, 27, 28]: 


$$
\mathrm{T}=\{(X 1, X 2, X 3, Y):(X 1, X 2, X 3) \text { can produce } Y\}
$$

To calculate the technical efficiency of $X 1$, the Shephard distance function of $X 1$ is defined as $[25,27$, 28]:

$$
D_{X 1}(X 1, X 2, X 3, Y)=\sup \{\alpha:(x 1 / \alpha, X 2, X 3, Y) \in T\}
$$

Since $D_{X 1}(X 1, X 2, X 3, Y) \geq 1$ the technical efficiency of $X 1$ is equal to $1 / D_{X 1}(X 1, X 2, X 3, Y)$.

SFA is used to calculate $D_{X 1}(X 1, X 2, X 3, Y)$. Suppose there are $\mathrm{n}$ decision marking units (DMU) in period t. Thus, the combination of input and output for the $i^{\text {th }}$ DMU is $\left(X 1_{i t}, X 2_{i t}, X 3_{i t}, Y_{i t}\right)$. Therefore, the Shephard distance function of $X 1$ can be expressed as $D_{X I}\left(X 1_{i t}, X 2_{i t}, X 3_{i t}, Y_{i}\right)$. After obtaining the translog of the Cobb-Douglas production function, Equation (3) is obtained $[25,27,28]$ :

$$
\begin{gathered}
\ln D_{X 1}\left(X 1_{i t}, X 2_{i t}, X 3_{i t}, Y_{i t}\right)=\beta_{0}+\beta_{X 1} \ln X 1_{i t}+\beta_{X 2} \ln X 2_{i t} \\
+\beta_{X 3} \ln X 3_{i t}+\beta_{Y} \ln Y_{i t}+V_{i t}
\end{gathered}
$$

...where $D_{X I}(\cdot)$ is the distance function and $V_{i t}$ is the statistical noise, which is assumed to be normally distributed. Because the distance function is homogeneous to one degree in the input, the above equation can be rearranged as $[25,27,28]$ :

$$
\begin{gathered}
\ln D_{X 1}\left(X 1_{i t}, X 2_{i t}, X 3_{i t}, Y_{i t}\right)=\ln X 1_{i t}+\beta_{0}+\beta_{X 1} \ln 1 \\
+\beta_{X 2} \ln X 2_{i t}+\beta_{X 3} \ln X 3_{i t}+\beta_{Y} \ln Y_{i t}+v_{i t}
\end{gathered}
$$

...which can be rewritten as:

$$
\begin{aligned}
-\ln X 1_{i t}= & \beta_{0}+\beta_{X 1} \ln 1+\beta_{X 2} \ln X 2_{i t}+\beta_{X 3} \ln X 3_{i t}+\beta_{Y} \ln Y_{i t} \\
& +v_{i t}-\ln D_{X 1}\left(X 1_{i t}, X 2_{i t}, X 3_{i t}, Y_{i t}\right)
\end{aligned}
$$

Thus,

$\ln \left(1 / X 1_{i t}\right)=\beta_{0}+\beta_{X 2} \ln X 2_{i t}+\beta_{X 3} \ln X 3_{i t}+\beta_{Y} \ln Y_{i t}+v_{i t}-u_{i t}$

Following Honma and $\mathrm{Hu}$ [25], where $u_{i t}$ is the inefficiency term, which follows a non-negative distribution, and $v_{i t}-u_{i t}$ is the error component term of a stochastic production frontier. Equation (6) is consistent with the panel data stochastic frontier model proposed by Battese and Coelli [29].

\section{Data and Empirical Model}

\section{Samples and Data Sources}

This study collected financial data over a period of eight years from listed solar energy companies in China and Taiwan. After removing companies whose main products were not solar energy products or who had incomplete data for the sample period, we obtained 32 solar energy companies in China and 16 solar energy companies in Taiwan, for a total sample of 48 companies and 384 data points. This study selected the number of employees (labour), operating costs, and R\&D costs as the three inputs and the gross output as the output. The sample data came from annual company financial reports in the databases of the Taiwan Economic Journal (TEJ). Since the sample period is eight years, we used the 2009 price index as the base period, applying deflators. In addition, because the currencies of China and Taiwan are different, both currencies were converted into US dollars using the average annual exchange rate of each currency.

\section{Variables}

The solar energy industry is a labour-intensive, material-intensive, and capital-intensive industry [30]. Urban et al. [31] believed that the solar energy industry is also a patent-intensive industry. Coad and Rao [32] argued that as the gross output and number of employees of a company increases, the $R \& D$ expenditure also increases.

Based on the characteristics of the solar energy industry, this study selected three input items - labour (L), operating costs (TC), and R\&D expenditures (R) as the input items, and gross output (net sales, Q) as the output item. The distance function models for each of the three inputs were constructed separately, and SFA was used to estimate the input efficiency of each item separately. This study also included environmental variables, including capital amount (CA) and raw

Table 1. Descriptive statistics of variables.

\begin{tabular}{|c|c|c|c|c|c|c|}
\hline Variables & Unit & Samples & Mean & Std. & Min. & Max. \\
\hline Total cost & USD\$1000 & 384 & 390,341 & 651,932 & 322 & $5,074,188$ \\
\hline Labour & person & 384 & 3,095 & 4,341 & 34 & 18,098 \\
\hline Net sales & USD\$1000 & 384 & 328,785 & 534,845 & 2,153 & $4,168,540$ \\
\hline R\&D expenditure & USD\$1000 & 384 & 10,807 & 23,107 & 23 & 211,191 \\
\hline Capital stock & USD\$1000 & 384 & 112,866 & 100,193 & 6,032 & 683,713 \\
\hline Raw material costs & USD\$1000 & 384 & 21,166 & 28,205 & 19 & 235,693 \\
\hline
\end{tabular}


material cost (RM). It also added a virtual variable (AREA) that distinguishes between China and Taiwan, where China is labelled as 1 , and Taiwan is labelled as 0 . The statistics of the variables in this study are listed in Table 1.

\section{Empirical Model}

This study combines the work of Zhou et al. [27] and Battese and Coelli [29], and also refers to the work of Honma and $\mathrm{Hu}$ [25] in order to construct a disaggregated input efficiency function model, as shown in Equation (6).

Labour input efficiency:

$$
\ln \left(1 / L_{i t}\right)=\beta_{0}+\beta_{T C} \ln T C_{i t}+\beta_{R} \ln R_{i t}+\beta_{Y} \ln Q_{i t}+v_{i t}-u_{i t}
$$

Operating cost input efficiency:

$$
\ln \left(1 / T C_{i t}\right)=\beta_{0}+\beta_{L} \ln L_{i t}+\beta_{R} \ln R_{i t}+\beta_{Y} \ln Q_{i t}+v_{i t}-u_{i t}
$$

R\&D investment efficiency:

$$
\ln \left(1 / R_{i t}\right)=\beta_{0}+\beta_{L} \ln L_{i t}+\beta_{T C} \ln T C_{i t}+\beta_{Y} \ln Q_{i t}+v_{i t}-u_{i t}
$$

This study also includes environmental variables in order to analyse the impact of environmental variables on $u_{i t}$.

$$
u_{i t}=\delta_{0}+\delta_{1} \ln C A_{j t}+\delta_{2} \ln R M_{j t}+\delta_{3} A R E A+\varepsilon_{i t}
$$

In this study, the estimating equations for the input efficiencies of each item are used to estimate the input efficiencies of each company, in order to analyse the impact of environmental variables on input efficiency. The efficiency analysis for the number of employees uses Equations (7) and (10) to calculate the labour input efficiency of each company and analyse the impact of environmental variables on labour input efficiency. Second, we used Equations (8) and (10) to calculate the operating cost input efficiency and analyse the impact of environmental variables on it. Finally, we used Equations (9) and (10) to calculate the R\&D input efficiency of each company in order to analyse the impact of environmental variables on $R \& D$ input efficiency. The free software "Frontier Version 4.1" can be used to estimate the equations, which was kindly provided by Professor Coelli [33].

\section{Results and Discussion}

\section{Analysis of Labour Efficiency}

Table 2 shows the result of stochastic frontier analysis of labour efficiency. Fig. 1 shows the average labour efficiency values for China and Taiwan in 2009-2016, which were 0.93 in China and 0.28 in Taiwan.

From Fig. 1 and the annual average values, we find polarised differences in the labour efficiency values between China and Taiwan. The results show that China has better labour efficiency and that Taiwan's labour efficiency is far lower than that of China, so there is still considerable room for improvement in Taiwan's labour force. In addition, the results in Table 2 show there is a significant negative correlation between operating costs and labour efficiency; R\&D spending has a strongly significant negative correlation with labour efficiency. The results for operating costs show that if a company wants to increase its production

Table 2. Estimates of the translog of labour force by frontier function.

\begin{tabular}{|c|c|c|c|c|}
\hline \multicolumn{5}{|c|}{ Table 2-1. Parameter estimates of the translog labour force frontier function } \\
\hline Variable description & Coefficient & Estimate & Standard error & t-ratio \\
\hline Constant & $\beta_{0}$ & 0.24802 & 0.49616 & 0.49987 \\
\hline InTC ${ }_{i t}$ & $\beta_{1}$ & -0.34525 & 0.14278 & $-2.41807^{*}$ \\
\hline $\operatorname{In} R_{i t}$ & $\beta_{2}$ & -0.11968 & 0.02667 & $-4.48693^{* *}$ \\
\hline $\operatorname{In} Q_{i t}$ & $\beta_{3}$ & -0.23833 & 0.14365 & $-1.65908^{*}$ \\
\hline \multicolumn{2}{|c|}{ Table 2-2. Estimates of the labour force inefficiency } \\
\hline$\delta_{0}$ & 4.44850 & 0.59508 & $7.47547^{* *}$ \\
\hline $\ln C A_{j t}$ & $\delta_{1}$ & -0.32571 & 0.05686 & $-5.72817^{* *}$ \\
\hline $\ln M_{j t}$ & $\delta_{2}$ & 0.06815 & 0.04996 & 1.36422 \\
\hline AREA & $\delta_{3}$ & -1.66489 & 0.13980 & $-11.90924 * *$ \\
\hline
\end{tabular}

Note: ${ }^{* *}$, and $*$ represent significance at the $1 \%$, and $5 \%$ levels, respectively. 


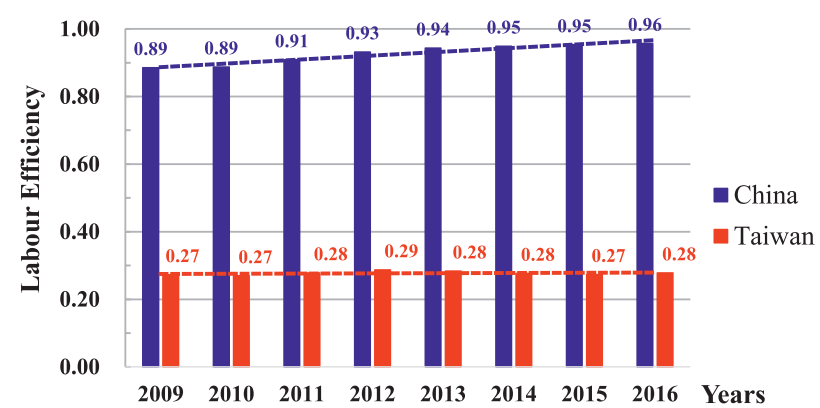

Fig. 1. The average labor force factor efficiency values for China and Taiwan in 2009-2016.

it needs to hire more employees. This also represents a positive relationship between cost expenditure and direct labour costs. In addition, high-tech companies must constantly research new products in order to increase market competitiveness and expand company size so as to avoid market obsolescence. This shows that increases in the number of employees and company size will be accompanied by increased R\&D spending. The results of this study are consistent with the findings of Coad and Rao [32]. When companies increase operating income and the number of employees, they will also increase R\&D expenditure.

With regard to the impact of environmental variables, there is a strongly significant negative correlation between the amount of capital and labour efficiency. The results of the research show that the larger the scale of the company, the better the labour efficiency. This may be because larger companies have better management capabilities, which will produce better labour performance. This result is consistent with the research results of Eling and Luhnen [15], Eken and Kale [34], and Dzeng and Wu [35]. However, they also reported that there is a limit to the scale efficiency of

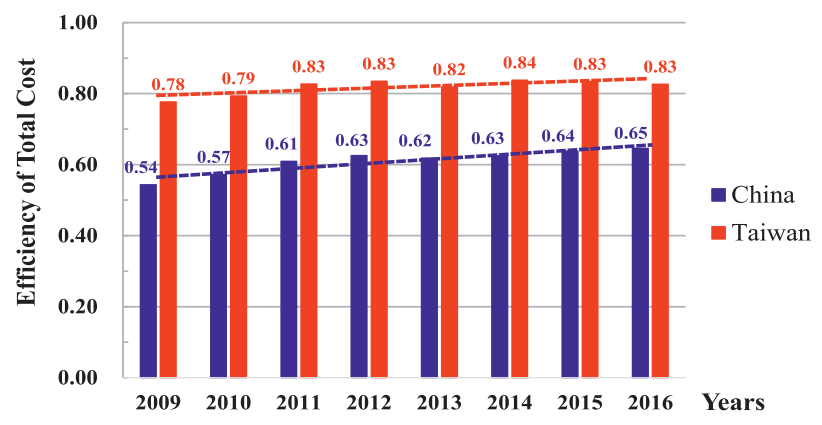

Fig. 2. Average total cost factor efficiency values for China and Taiwan in 2009-2016.

a company. It is not efficient to expand the scale of the company indefinitely, and this may actually become counterproductive.

In addition, there is a strongly significant negative correlation between the dummy variable for labour efficiency and area. In other words, there are strongly significant differences between the labour forces in China and Taiwan. Although China and Taiwan have the same culture and race, after 50-60 years of separation, there are extremely large differences in many beliefs. First, labour costs in China are lower than in Taiwan. Although they have begun to close in recent years, there are still big differences in the salaries of operations workers. Second, through employee training systems and standardised operating procedures, the high-tech industry in China is able to apply strict internal control, establish workplace concepts and operating techniques, increase team spirit, and achieve management objectives. However, at present, China's low salaries, long working hours, and centralised management methods may only deliver better labour results in the short term. As time progresses, differences in how different generations view work, the era of high productivity, and low wages

Table 3. Estimates of the translog of total cost by frontier function.

\begin{tabular}{|c|c|c|c|c|}
\hline \multicolumn{5}{|c|}{ Table 3-1. Parameter estimates of the translog total cost frontier function } \\
\hline Variable description & Coefficient & Estimate & Standard error & t-ratio \\
\hline Constant & $\beta_{0}$ & -2.12371 & 0.16968 & $-12.51570^{* *}$ \\
\hline $\operatorname{In} L_{i t}$ & $\beta_{1}$ & -0.04992 & 0.01651 & $-3.02393 * *$ \\
\hline $\operatorname{In} R_{i t}$ & $\beta_{2}$ & -0.00170 & 0.00913 & -0.18598 \\
\hline $\operatorname{In} Q_{i t}$ & $\beta_{3}$ & -0.81482 & 0.01685 & $-48.34704 * *$ \\
\hline Constant & $\delta_{0}$ Table 3-2. Estimates of total cost inefficiency & 0.21107 & $11.35680^{* *}$ \\
\hline $\ln C A_{j t}$ & $\delta_{1}$ & 2.39706 & 0.01515 & $-9.75546^{* *}$ \\
\hline $\ln M_{j t}$ & $\delta_{2}$ & -0.14778 & 0.01341 & $-4.78245^{* *}$ \\
\hline$A R E A$ & $\delta_{3}$ & -0.06413 & 0.04337 & $8.52399^{* *}$ \\
\hline
\end{tabular}

Note: ${ }^{* *}$, and $*$ represent significance at the $1 \%$, and $5 \%$ levels, respectively. 
Table 4. Estimates of the translog of R\&D by frontier function.

\begin{tabular}{|c|c|c|c|c|}
\hline Variable description & Coefficient & Estimate & Standard error & t-ratio \\
\hline Constant & $\beta_{0}$ & -1.24600 & 0.42359 & $-2.94152 * *$ \\
\hline $\operatorname{In} L_{i t}$ & $\beta_{1}$ & -0.55280 & 0.05480 & $-10.08773 * *$ \\
\hline $\operatorname{In} T C_{i t}$ & $\beta_{2}$ & -0.02051 & 0.16909 & -0.12130 \\
\hline $\operatorname{In} Q_{i t}$ & $\beta_{3}$ & -0.29453 & 0.15553 & -1.89372 \\
\hline \multicolumn{5}{|c|}{ Table 4-2. Estimates of R\&D inefficiency } \\
\hline Constant & $\delta_{0}$ & -54.27044 & 31.23735 & -1.73736 \\
\hline $\ln C A_{j t}$ & $\delta_{1}$ & 1.05549 & 0.68800 & 1.53415 \\
\hline $\ln M_{j t}$ & $\delta_{2}$ & 1.31433 & 0.97271 & 1.35121 \\
\hline AREA & $\delta_{3}$ & 4.80358 & 2.71121 & 1.77175 \\
\hline \multicolumn{5}{|c|}{$\log$ likelihood function $=-516.83652$} \\
\hline
\end{tabular}

Note: ${ }^{* *}$, and $*$ represent significance at the $1 \%$, and $5 \%$ levels, respectively.

will quickly disappear. For this area, policy makers and managers should actively seek new strategies to respond and adapt to future changes.

\section{Operating Costs Input Efficiency Analysis}

Table 3 shows the results of the stochastic frontier analysis of operating cost efficiency. Fig. 2 shows the average operating cost efficiencies for China and Taiwan in 2009-2016, which were 0.61 in China and 0.82 in Taiwan.

As shown in Fig. 2, Taiwan's operating cost efficiency is better than China's, but there is still room for improvement in both areas. In addition, as shown in Table 3, the number of employees and gross output have a strong negative correlation with operating cost efficiency. The amount of capital in environmental variables also has a strong negative correlation with operating cost efficiency. These three items all show that larger companies have better cost efficiency. This may be because larger companies can use more resources and are more competitive in the market.

With regard to the impact of environmental variables, raw materials also have a strong negative correlation with operating cost efficiency. This shows that the prices of raw materials have a direct impact on operating costs. Silicon is the most important basic raw material for the semiconductor and solar cell industries. In other words, the market prices of silicon raw materials will be one of the main factors that directly affect the profitability of a solar company. In addition, the area dummy variable has a strongly significant positive correlation with operating cost efficiency. This shows that there are indeed differences between the operating cost efficiencies of China and Taiwan. The estimates show that the performance of Taiwan is 1.3 times greater than that of China.

\section{R\&D Cost Input Efficiency Analysis}

Table 4 shows the results of the stochastic frontier analysis for R\&D expenditures. Figure 3 shows the average efficiencies for R\&D expenditures for China and Taiwan in 2009-2016, which were 0.50 in China and 0.49 in Taiwan.

As Table 4 shows, R\&D expenditure inefficiency has a strongly significant negative correlation with the labour force. This estimate is the same as the result of the previous labour efficiency analysis. As shown in Fig. 3 and by the input efficiency values, the R\&D expenditures in both China and Taiwan are inefficient and have considerable room for improvement. In addition, the present study used statistics from the financial statements of solar companies in China and Taiwan, which showed that the rate of expenditure on $R \& D$ in both areas is low (R\&D expenditure rate $=$ (operating expenses on R\&D) / (net operating income) $\times 100 \%$ ). During the sample period from 2009 to 2016 , the annual average for the two areas was only

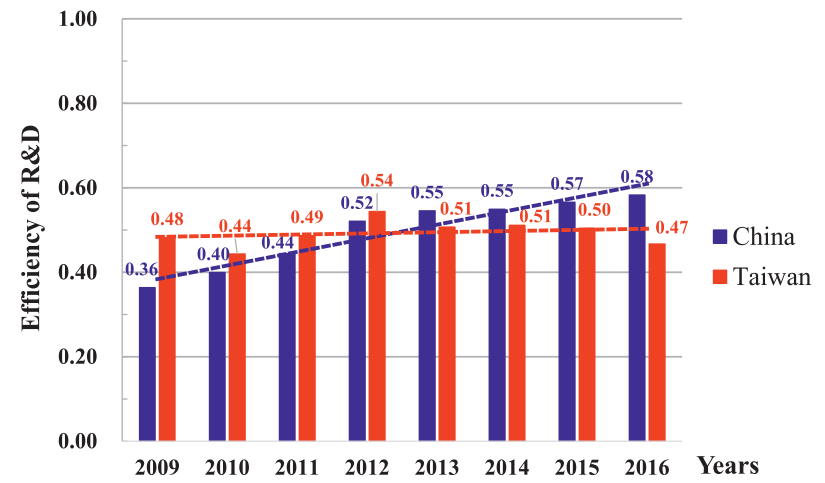

Fig. 3. Average R\&D factor efficiency values for China and Taiwan in 2009-2016. 
approximately $5 \%$. The results of this study are in line with the findings of Wang et al. [36] that the R\&D efficiency of solar energy companies is not good.

In addition, Ferroni and Hopkirk [30] analysed the influence of the development of patent technologies on the market value of South Korean renewable energy listed companies over 35 years from 1980 to 2014. Their research showed that patented technologies have a very significant impact on the market values of companies. In other words, patented technologies can increase the economic value of renewable energy companies.

At present, different technologies in the solar energy industry have the issue of high costs. The most important of these are patented technologies for solar energy products that have been blocked by Western countries. These technological gaps lead to increases in production costs. If there is insufficient investment in R\&D in the solar energy industry in China and Taiwan, then a lack of core technologies, market price competition, technological development, and financial arrangements will all affect the development of the solar industry. If China or Taiwan fail to actively increase R\&D expenditures, improve technology, and increase product differentiation to expand their economic scales, then they will have difficulty coping with the pressure of global economic competition and may face elimination from the market.

\section{Conclusions}

Since the industrial revolution of the 1750 s, human economic activities have developed rapidly. Fossil energy resources such as coal, oil and natural gas account for the largest proportion of energy worldwide, and they also produce more environmental pollution (such as $\mathrm{CO}_{2}, \mathrm{CH}_{4}, \mathrm{~N}_{2} \mathrm{O}$ and $\mathrm{O}_{3}$ ). The extensive burning of fossil fuels in the atmosphere leads to climate change - which along with the depletion of fossil fuels are the biggest challenges that humanity faces today. Energy researchers and policy decision makers around the world are now placing special focus on solar energy, as it is one of the most non-polluting, inexhaustible and cleanest renewable energy sources.

Although China and Taiwan respectively occupy first and second place in the current global output of solar energy products, they face serious pressure in the international market. In order to measure the operating efficiency of solar energy companies in China and Taiwan, this study used the Shephard distance function to define the efficiency of different items in solar energy companies. The study applied stochastic frontier analysis and incorporated environmental variables to measure the operating efficiencies of solar energy companies. The study sample contained 384 financial data points of 48 solar energy companies in China and Taiwan over a period of eight years (2009-2016). The main empirical findings are: (1) China has better labour efficiency, (2) Taiwan has better operating cost efficiency, (3) both regions have extremely poor expenditure efficiency on research and development (R\&D) and the $R \& D$ expenditure rate is low (approximately 5\% of net operating income), (4) the larger a company's size, the higher the labour force efficiency and cost efficiency and (5) the prices of raw materials have a direct impact on operating costs.

Based on the results of this study, we suggest that the solar industry adopt the following strategies for improvement: (1) adopt automated production to reduce labour demand and costs in order to increase production efficiency; (2) appropriately expand the economic scale of companies to improve labour efficiency and cost efficiency; (3) increase $R \& D$ costs to develop new core patent technologies, improve technology, increase product differentiation, reduce product costs, and face international market competition; and (4) search for alternative raw materials in order to reduce the risk of cost increases caused by fluctuations in the price of raw materials.

It is hoped that the results of this research will gain the attention of solar energy companies in China and Taiwan and help them to decrease their operating costs and improve their management strategies. The results and recommendations of this research can be applied to the solar energy industry in other countries.

\section{Data Availability Statement}

The sample data came from annual company financial reports in the databases of the Taiwan Economic Journal (TEJ). All data generated or used during the study are available from the corresponding author by request.

- The data of 32 solar energy companies in China and 16 solar energy companies in Taiwan, for a total sample of 48 companies and 384 data points.

- Models generated or used during the study appear in the submitted article.

\section{Acknowledgements}

The free software "Frontier Version 4.1" used to estimate equations was kindly provided by Professor Coelli (1996). Valuable suggestions from the reviewers as well as the editors are highly appreciated.

\section{Conflict of Interest}

The authors declare no conflict of interest.

\section{References}

1. NATIONAL OCEANIC AND ATMOSPHERIC ADMINISTRATION. Trends in Atmospheric Carbon 
Dioxide. https://www.esrl.noaa.gov/gmd/ccgg/trends/ global.html (accessed on 3 July 2018)

2. LEE Y.S., TONG L.I. Predicting High or Low Transfer Efficiency of Photovoltaic Systems Using a Novel Hybrid Methodology Combining Rough Set Theory, Data Envelopment Analysis and Genetic Programming. Energies, 5 (3), 545, 2012.

3. BP P.L.C. STATISTICAL REVIEW OF WORLD ENERGY. https://www.bp.com/en/global/corporate/ energy-economics/statistical-review-of-world-energy.html/ (accessed on 12 April 2018).

4. LIU J., LONG Y., SONG X. A Study on the Conduction Mechanism and Evaluation of the Comprehensive Efficiency of Photovoltaic Power Generation in China. Energies, 10 (5), 1, 2017.

5. RAMANA M.V. Nuclear Power: Economic, Safety, Health, and Environmental Issues of Near-Term Technologies. Annual Review of Environment and Resources, 34, 127, 2009.

6. MINTS P., HOPWOOD D. Can solar PV beat the downturn. Renewable Energy Focus, 9, 62, 2009.

7. GHOSHA S., YADAVB V.K., MUKHERJEEC V., YADAVB P. Evaluation of relative impact of aerosols on photovoltaic cells through combined Shannon's entropy and Data Envelopment Analysis (DEA). Renewable Energy, 105, 344, 2017.

8. SAHU B.K. A study on global solar PV energy developments and policies with special focus on the top ten solar PV power producing countries. Renewable and Sustainable Energy Reviews, 43, 621, 2015.

9. MARADIN D., CEROVI L. Possibilities of Applying the DEA Method in the Assessment of Efficiency of Companies in the Electric Power Industry: Review of Wind Energy Companies. International Journal of Energy Economics and Policy, 4 (3), 320, 2014.

10. ERVURAL B.C., ERVURAL B., ZAIM S. Energy Efficiency Evaluation of Provinces in Turkey Using Data Envelopment Analysis. Procedia - Social and Behavioral Sciences, 235, 139, 2016.

11. DEPARTMENT OF ENERGY USA. Energy Sources: Solar. https://www.energy.gov/science-innovation/energysources/renewable-energy/solar. 2011. (accessed on 3 July 2018).

12. WIKIPEDIA. SOLAR POWER. https://en.wikipedia.org/ wiki/Solar_power (accessed on 3 July 2018).

13. INTERNATIONAL ENERGY AGENCY. Technology Roadmap: Solar Photovoltaic Energy. 2014, http://www.iea. org/termsandconditionsuseandcopyright/. 2014. (accessed on 3 July 2018)

14. PLATZER, M.D. U.S. Solar Photovoltaic Manufacturing: Industry Trends, Global Competition, Federal Support. EveryCRSReport. https://www.everycrsreport.com/ reports/R42509.html/. 2015. (accessed on 7 April 2018).

15. ELING M., LUHNEN M. Efficiency in the international insurance industry: A cross-country comparison. Journal of Banking \& Finance, 34 (7), 1497, 2010.

16. FARRELL M.J. The measurement of productive efficiency. Journal of the Royal Statistical Society, 120 (3), 253, 1957.

17. CAMANHO A.S, DYSON R.G. Cost efficiency measurement with price uncertainty: a DEA application to bank branch assessments. European Journal of Operational Research, 161, 432, 2005.

18. WU A.H., CAO Y.Y., LIU B. Energy efficiency evaluation for regions in China: an application of DEA and Malmquist indices. Energy Efficiency, 7 (3), 429, 2014.
19. CHEN M., SHIHONG Z. The Study on New Energy Industry Investment Efficiency in China. Management \& Engineering, 16, 69, 2014.

20. TU C.J., CHANG M.C., CHENG C.P. Progressive TimeWeighted Dynamic Energy Efficiency, Energy Decoupling Rate, and Decarbonization: An Empirical Study on G7 and BRICS. Sustainability, 8 (9), 928, 2016.

21. CHUEH H.E., JHENG J.Y. Evaluation of Taiwanese Solar Cell Industry Operational Performance Using Two-Stage Data Envelopment Analysis. Applied Mechanics and Materials, 224, 51, 2012.

22. LEE H.I., LIN C.Y., KANG H.Y., LEE W.H. An Integrated Performance Evaluation Model for the Photovoltaics Industry. Energies, 5 (4), 1271, 2012.

23. STERN D.I. Modeling international trends in energy efficiency. Energy Economics, 34 (6), 2200, 2012.

24. HERRALA R., GOEL R.K. Global CO2 efficiency: country-wise estimates using a stochastic cost frontier. Energy Policy, 45, 762, 2012.

25. HONMA S., HU J.L. A panel data parametric frontier technique for measuring total-factor energy efficiency: An application to Japanese regions. Energy, 78, 732, 2014.

26. LEE H.I., KANG H.Y., LIN C.Y., SHEN K.C. An Integrated Decision-Making Model for the Location of a PV Solar Plant. Sustainability, 7 (10), 13522, 2015.

27. ZHOU P., ANG B.W., ZHOU D.Q. Measuring economywide energy efficiency performance: A parametric frontier approach. Applied Energy, 90, 196, 2012.

28. HU J.L., CHANG T.P., ZHU X.H. A Comparative Study of Disaggregate Input Efficiency of Life Insurance Industry across the Taiwan Strait: An Application of the Stochastic Frontier Analysis. School Journal of Economics and Business, 85, 41, 2014. (in Chinese).

29. BATTESE G.E., COELLI T.J. A model for technical inefficiency effects in a stochastic frontier production function for panel data. Empirical Economics, 20 (2), 325, 1995.

30. FERRONI F., HOPKIRK R.J. Energy Return on Energy Invested (ERoEI) for photovoltaic solar systems in regions of moderate insolation. Energy Policy, 94, 336, 2016.

31. URBAN F., GEALL S., WANG Y. Solar PV and solar water heaters in China: Different pathways to low carbon energy. Renewable and Sustainable Energy Reviews, 64, 531, 2016.

32. COAD A., RAO R. Firm growth and R\&D expenditure. Economics of Innovation and New Technology, 19 (2), 127, 2010.

33. COELLI T.J. A Guide to FRONTIER Version 4.1: A Computer Program for Stochastic Frontier Production and Cost Function Estimation. CEPA Working Paper No. 7/96, Armidale, NSW, Australia: Department of Econometrics, University of New England. 1996.

34. EKEN M.H., KALE S. Measuring bank branch performance using Data Envelopment Analysis (DEA): The case of Turkish bank branches. African Journal of Business Management, 5 (3), 889, 2011.

35. DZENG R.J., WU J.S. Efficiency Measurement of the Construction Industry in Taiwan: A Stochastic Frontier Cost Function Approach. Construction Management and Economics, 31 (4), 335, 2013.

36. WANG Q., HANG Y., SUN L., ZHAO Z. Two-stage innovation efficiency of new energy enterprises in China: A non-radial DEA approach. Technological Forecasting and Social Change, 112, 254, 2016. 
